\title{
PENGARUH DIFERENSIASI PRODUK “GREEN TOURISM DESTINATION” TERHADAP KEPUASAN BERKUNJUNG DI PULAU SIKUAI
}

(Survey terhadap pengunjung di Pulau Sikuai Sumatera Barat)

\author{
Dian Permana \\ Ridwan Purnama \\ Rini Andari \\ Manajemen Pemasaran Pariwisata FPIPS UPI
}

\begin{abstract}
The development and growth of maritime tourism in Indonesia nowadays become a prominence that can be created as a maritime destination in world level. Indonesia's Sabang until Merauke store millions of the beauty of natures that are unique and can not be found in other place even there are not many people know it. One of many potentials that Indonesia has, there is Pulau Sikuai which is located in Pantai Padang, West Sumatera. Pulau Sikuai in its development does really keep and concern about the natural of environment, and also support the "green" concept that is being conducted by the local government and central government. So as it becomes own differentiation of Pulau Sikuai in giving the product and more satisfaction to the visitors because of taking part in preserving nature and environment. The product differentiation of Pulau Sikuai "green tourism destination" consists of features, performance, style and design. Based on the explanation, the research is done to know about the visiting satisfaction that is viewed from product differentiation "green tourism destination". Analysis unit of the research is the visitors with the population reaches until 80 persons. The method that is done in this research is descriptive method and verification method, the research is conducted in less than one year period of time, so that it is used cross sectional method. The data that is used is primary data and secondary data which is conducted through literature study and questionnaire. To measure how big the impact of product differentiation "green tourism destination" to the visiting satisfaction in Pulau Sikuai, the multiple regression is performed. Based on the hypothesis statistic, product differentiation "green tourism destination" which consists of features, performance, style and design can influence the visiting satisfaction in Pulau Sikuai. Where the variable features mempengaruih visit satisfaction of $34.82 \%$, while affecting the performance of $17.52 \%$ visit satisfaction, style and design affect the satisfaction of visiting at 3.06\%.
\end{abstract}

Key words: product differentiation green tourism destination, visiting satisfaction.

\section{I . PENDAHULUAN}

\subsection{Latar Belakang Penelitian}

Melakukan aktivitas perjalanan yang dilakukan untuk sementara waktu dari tempat tinggal semula ke daerah tujuan dengan alasan bukan untuk menetap atau mencari nafkah melainkan hanya untuk bersenang-senang, memenuhi rasa ingin tahu, menghabiskan waktu senggang atau waktu libur serta tujuan-tujuan lainya disebut dengan wisata. Menurut Buchli dalam Yoeti (2007:5) mengatakan bahwa pariwisata adalah setiap peralihan tempat yang bersifat sementara dari seseorang atau beberapa orang dengan maksud memperoleh pelayanan yang diperuntukan bagi kepariwisataan itu oleh lembaga-lembaga yang digunakan untuk maksud tersebut. Berdasarkan Undang-undang Republik Indonesia Nomor 10 Tahun 2009 pariwisata adalah berbagai macam kegiatan wisata dan didukung berbagai fasilitas serta layanan yang disediakan oleh masyarakat, pengusaha, Pemerintah dan Pemerintah daerah.

Memanfaatkan Indonesia sebagai Negara Maritim yang terdiri dari 17.504 pulau dan terletak di garis khatulistiwa menjadikannya salah satu negara yang berpotensi menjadi tujuan destinasi bahari kelas dunia. Indonesia didukung oleh 75.000 $\mathrm{km} 2$ laut dengan $81.000 \mathrm{~km}$ garis pantai di dalamnya terdapat 950 spesies terumbu karang, 8.500 spesies ikan tropis, 555 spesies rumput laut, dan 18 spesies padang lamun. Potensi maritim ini memiliki prospek besar, salah satunya dalam wisata bahari. Menurut GAHAWISRI (Gabungan Pengusaha Wisata Bahari) dalam dalam situsnya mengatakan, potensi wisata bahari mencapai 2 juta miliar dolar, sehingga sangat menguntungkan kedepan apabila 
pariwisata bahari di Indonesia dapat dikembangkan dengan baik dan profesional.

Pada tahun 2007 Provinsi Sumatera Barat oleh Departemen Kebudayan dan Pariwisata telah ditetapkan salah satu dari lima daerah di Indonesia yang dijadikan sebagai daerah destinasi unggulan Hal ini merupakan kesempatan untuk mengembangkan dan mempromosikan potensi wisata, khususnya wisata bahari atau kawasan pesisir yang terdapat di Sumatera Barat. Kawasan pesisir Sumatera Barat memiliki potensi yang luar biasa dan prospek untuk dikembangkan. Selain kekayaan laut yang masih belum tergarap dengan optimal, kawasan-kawasan ini memiliki objek wisata yang bisa dikembangkan secara luas.

Pulau Sikuai merupakan salah satu pulau yang sudah memiliki manajemen yang baik, karena pengelolaan oleh pihak swasta. Pulau ini masuk ke dalam wilayah kecamatan Bungus Teluk Kabung, 23 Km arah selatan Kota Padang. Pulau ini terletak sekitar setengah mil laut dari pusat kota dan dapat dicapai dengan menggunakan transportasi laut speed boat, dibutuhkan waktu tempuh sekitar 45 menit dari pelabuhan Muaro Padang. Menjadi daerah tujuan wisata dan objek wisata bahari unggulan di Kota Padang, manajemen Pulau Sikuai telah memfasilitasi pulau ini dengan hotel resort setaraf hotel berbintang tiga yang bernama New Sikuai Island Resort. Sekitar 2.4 Ha dari luas pulau ini telah digunakan sebagai kawasan resort sedangkan sisanya masih berupa kawasan hutan dan pantai.

Hal ini dimanfaatkan oleh pihak manajemen Sikuai dalam promosi dan meningkatkan kepuasan berkunjung di Pulau Sikuai dengan menerapkan konsep diferensiasi produk melalui green tourism destination. Konsep green tourism destination mencakup program-program wisata yang meminimalkan aspek-aspek negatif dari pariwisata konvensional atau wisata yang dikemas dalam paket-paket wisata, serta memerlukan sarana dan fasilitas yang mewah berskala besar terhadap lingkungan dan meningkatkan integritas budaya masyarakat setempat. Oleh karena itu, selain mengevaluasi budaya dan faktor lingkungan, green tourism destination juga merupakan bagian integral dari kegiatan promosi daur ulang, efisiensi energi, konservasi air, dan penciptaan peluang ekonomi bagi masyarakat setempat.
Praktek green tourism destination berarti keberlanjutan akan lingkungan, kebudayaan, dan juga komunitas pada lokasi wisata yang dikunjungi. Pemasaran konsep ini sangat memberikan keuntungan jangka panjang dan ketahanan bisnis tergantung pada pemeliharaan lingkungan yang menarik dan sehat, diantaranya menghemat biaya, sejalan dengan ketentuan per-undang-undangan, menghindari terjadinya relasi negatif dengan publik, memenuhi peningkatan ekpektasi dan permintaan pengunjung, mencapai keuntungan yang berdaya saing, dan mengurangi biaya operasional. Green tourism destination sama halnya dengan Ecotravel, Ecovacation, Eco - (ad)venture, Eco - cruise, Eco - safari, Nature tourism (wisata alam), Low impact tourism, Bio tourism, Ecologically responsible tourism yang memang biasa digunakan dalam istilah marketing bisnis pariwisata berbasis ekosistem, menurut The International Ecotourism Society (TIES).

Berdasarkan penerapan green tourism destination, Pulau Sikuai dengan diferensiasinya pada feature, performance serta style and design, maka Pulau Sikuai lebih menjaga kelestarian alamnya, menjaga kebersihan alam, melengkapi fasilitas, yang ramah lingkungan, meningkatkan pelayanan, menjaga kebudayaan dan mengatur tata letak (zonasi) di Pulau Sikuai. Hal tersebut dikarenakan agar Pulau Sikuai lebih menarik dan berbeda dengan kawasan wisata lainnya dan wisatawan yang datang merasa puas dan berperan serta dalam menjaga lingkungan alam apabila berada di Pulau Sikuai. Dengan produk-produk berkelanjutan dan ramah lingkungan yang ditawarkan di Pulau Sikuai membuat pengunjung merasakan pengalaman yang berbeda dan menciptakan kepuasan tersendiri, serta mendukung green tourism destination. Pengunjung tidak menemukan di pulau-pulau lain yang ada di pesisir Sumatera Barat. Ini menunjukkan bahwa untuk kawasan wisata Pulau Sikuai yang dikelola berbasiskan perbedaan atau keunikan merupakan pemimpin dan sebagai suatu pulau yang sangat diminati oleh pengunjung.

Penerapan diferensiasi produk yang berbasis green tourism destination diharapkan juga dapat membuat perbedaan sehingga berdampak lanjut terhadap komunitas lokal yang terlibat langsung. Selain itu penerapan ini dapat meminimalisir perusakan terhadap alam, 
mendukung perlindungan suatu kawasan, mengedepankan pemberdayaan komunitas lokal, mengapresiasi lebih kebudayaan dan nilai lokal, serta berfungsi untuk meningkatkan kesadaran masyarakat terhadap konservasi alam dan lingkungan sekitarnya (Special Report, The U.S. Ecotourism Market, WTO, 2002). Adanya penerapan diferensiasi produk pada wisata yang disediakan Pulau Sikuai maka diharapkan kepuasan para pengunjung kedepannya akan menjadi meningkat.

Berdasarkan dari penjelasan yang dipaparkan, maka perlu diadakan suatu penelitian mengenai diferensiasi produk yang diterapkan oleh pihak Pulau Sikuai terhadap kepuasan yang dirasakan oleh pengunjung yang datang di Pulau tersebut, maka peneliti tertarik untuk melakukan penelitian tentang "Pengaruh Diferensiasi Produk Green Tourism Destination Terhadap Kepuasan Berkunjung Di Pulau Sikuai" (Survey terhadap pengunjung di Pulau Sikuai Sumatera Barat).

\subsection{Rumusan Masalah}

Berdasarkan latar belakang masalah diatas, rumusan masalah yang dapat ditarik adalah:

1. Bagaimana pengaruh diferensiasi produk green tourism destination di Pulau Sikuai.

2. Bagaimana kepuasan berkunjung pengunjung di Pulau Sikuai.

3. Sejauh mana pengaruh diferensiasi produk green tourism destination terhadap kepuasan berkunjung pengunjung.

\subsection{Tujuan Penelitian}

Adapun tujuan penelitian yang ingin diketahui oleh peneliti, yaitu untuk memperoleh gambaran terhadap:

1. Diferensiasi produk green tourism destination di Pulau Sikuai.

2. Kepuasan berkunjung pengunjung di Pulau Sikuai.

3. Untuk mendapatkan informasi tentang sejauh mana pengaruh diferensiasi produk green tourism destination terhadap kepuasan berkunjung pengunjung di Pulau Sikuai.

\subsection{Kegunaan Penelitian \\ 1. Kegunaan Akademis}

Penelitian ini berguna secara akademis untuk menelaah kembali teori-teori mengenai diferensiasi produk green tourism destination. Diharapkan, dari penelitian ini dihasilkan suatu data yang berguna, sehingga dapat memberikan masukan untuk pengembangan teori mengenai diferensiasi produk green tourism destination di masa yang akan datang.

2. Kegunaan Praktis

Penelitian ini berguna sebagai acuan dalam membantu serta menyusun strategi pemasaran bagi pihak manajemen New Sikuai Island Resort sebagai pengelola Pulau Sikuai untuk menambah kepuasan berkunjung di Pulau Sikuai dan mengambil kebijakan yang berkaitan dengan konsumen

\section{KERANGKA PEMIKIRAN DAN} HIPOTESIS

\subsection{Kerangka Pemikiran}

Tujuan dari pemasaran adalah memenuhi dan memuaskan kebutuhan dan keinginan kosumen dalam hal ini adalah pengunjung. Tidak mudah bagi pemasar dalam memenuhi dan memuaskan kebutuhan itu, kemudian muncul strategi yang dapat menjawab semua permasalahan yang tentang pemuasan kebutuhan pengunjung. Strategi yang diterapkan diharapkan juga dapat mengantisipasi pesaing lain yang memberikan penyediaan produk atau jasa yang sama.

Salah satu strategi yang dimanfaatkan saat ini adalah menerapkan strategi yang menerapkan alat bantu pemasaran, marketing mix. Marketing mix merupakan variabel-variabel yang akan diawasi yang disusun oleh perusahaan tersebut untuk memuaskan kelompok yang ditarget (Canon Perreault et McCarthy, 2008:40). Variabel bauran pemasaran menurut Kotler dan Keller (2009:63) terdiri dari Product, Price, Place, Promotion, People, Process, dan Customer service. Masing-masing variabel ini saling berkaitan satu dengan yang lainnya. Apabila terdapat kekurangan didalam penerapan, maka proses pemasaran akan menjadi tidak lancar dan tujuan pencapaian dari pemasaran akan terganggu.

Produk merupakan salah satu variabel yang utama dalam bauran pemasaran yang bisa menentukan kepuasan dari seorang pengunjung objek wisata. Fandy Tjiptono 
(2008:95) produk merupakan sesuatu yang dapat ditawarkan produsen untuk diperjatikan, diminta, dicari, dibeli dan digunakan atau dikonsumsi pasar sebagai pemenuhan kebutuhan dan keinginan pasar yang bersangkutan. Produk ditawarkan meliputi barang fisik, jasa, orang atau pribadi, organisasi dan ide. jadi produk bisa berupa manfaat tangible maupun intangible. secara konseptual, produk adalah pemahaman subyektif dari produsen atas sesuatu yang bisa ditawarkan sebagai usaha untuk mencapai tujuan organisasi melalui pemenuhan kebutuhan dan keinginan konsumen, sesuai dengan kompetensi dan kapasitas organisasi serta daya beli pasar, selain itu produk dapat didefinisikan sebagai persepsi konsumen yang dijabarkan oleh produsen melalui hasil produknya. Dalam pariwisata produk pariwisata adalah produk wisata, dimana barang-barang persediaan pariwisata yang disediakan oleh kelompok-kelompok industri pariwisata sebagai kebutuhan yang dikehendaki oleh wisatawan, baik dalam hubungan sentra maupun objek sentra, baik bersifat material maupun non material (Nyoman S Pendit, 2006:125)

Menghadapi persaingan dengan penyedia produk dan jasa lain yang sejenis, hal ini membuat produk menjadi fokus utama dalam memenangkan persaingan. Produk akan dimodifikasi dan dibedakan sehingga membuat suatu perbedaan yang mencolok bagi pengunjung yang akan berkunjung. Strategi pembedaan produk, mendorong perusahaan untuk sanggup menemukan keunikan tersendiri dalam pasar yang menjadi sasaran. Keunikan produk (barang atau jasa) yang diandalkan ini memungkinkan suatu perusahaan untuk menarik minat sebesar-besarnya dari pengunjung potensial sehingga bisa menciptakan kepuasan. Cara pembedaan produk bervariasi dari pasar ke pasar, tetapi berkaitan dengan sifat dan atribut fisik suatu produk atau pengalaman kepuasan yang didapat oleh pengunjung dari produk atau jasa tersebut. features, aksesibilitas, kenyamanan dan berbagai hal lain yang sulit ditiru lawan merupakan sedikit contoh diferensiasi.

Diferensiasi produk itu sendiri adalah menurut Kotler (2008:328) tindakan merancang serangkaian perbedaan yang berarti untuk membedakan tawaran perusahaan dengan tawaran pesaing. Sedangkan menurut Mowen dan Miror
(2007:55) diferensiasi adalah proses manipulasi bauran pemasaran untuk menempatkan sebuah merek sehingga para konsumen dapat merasakan perbedaan yang berarti antara merek tersebut dengan pesaing. Secara umum, terdapat dua bidang syarat yang harus dipenuhi dalam memanfaatkan strategi ini, yaitu bidang sumber daya dan bidang organisasi. dari sisi sumber daya perusahaan, dibutuhkan kekuatan dalam hal pemasaran, kreativitas, dan bakat perekayasaan produk, riset pasar, reputasi perusahaan, distribusi dan keterampilan kerja. sedangkan dari organisasi, perusahaan harus kuat dan mampu untuk melakukan koordinasi antar fungsi manajemen yang terkait.

Perusahaan harus dapat mendiferensiasikan produknya agar dapat menghadapi persaingan yang semakin ketat diantara perusahaan-perusahaan yang memproduksi barang sejenis. Strategi diferensiasi produk yang diterapkan oleh Pulau Sikuai adalah green tourism destination yang merupakan suatu destinasi tujuan wisata yang berkelanjutan dan ramah lingkungan serta melakukan konservasi terhadap lingkungan.

Variabel utama diferensiasi produk menurut Kotler dan Amstrong (2011:211) yang digunakan pada penelitian ini adalah features (keistimewaan) dimana objek wisata dapat ditawarkan merupakan objek wisata unggulan dan menunjukan karakteristik dari Pulau Sikuai. Performance (kinerja) merupakan pelayanan dan jenis wisata yang diberikan yang diberikan kepada wisatawan yang datang ke Pulau Sikuai dapat memuaskan, serta style and design (gaya dan desain) merupakan penampilan dan perasaan wisatawan pada objek wisata Pulau Sikuai, karena objek wisata Pulau Sikuai berbeda dengan pulau lainnya

Penerapan variabel diatas, apabila dimanfaatkan oleh penyedia jasa pariwisata dengan baik khsusnya Pulau Sikuai, hal ini akan menciptakan kepuasan tersendiri bagi para pengunjung yang datang kepulau tersebut. Diferensiasi produk ini juga akan membantu Sikuai dalam mengantisipasi para pesaing lain yang dianggap kuat seperti Pulau Cubadak di Pesisir Selatan.

Kepuasan yang dihasilkan oleh pengaruh strategi diferensiasi produk, ditentukan oleh ekspektasi dan persepsi pengunjung. Jika manfaat yang dirasakan lebih kecil dari harapan maka pengunjung 
akan merasa tidak puas dan tidak senang. Begitu juga ketika manfaat sesuai dengan harapan maka pelanggan akan merasa senang (Kotler dan Keller 2009:164).

Fandi Tjiptono dan Gregorius (2005:205), mengungkapkan bahwa ekspektasi berfungsi sebagai standar perbandingan. Kinerja produk atau jasa pada berbagai dimensi dibandingkan dengan ekspektasi. Perbandingan tersebut akan menghasilkan reaksi konsumen terhadap produk dan jasa dalam bentuk kepuasan atau persepsi kualitas.

Persepsi adalah keyakinan mengenai produk atau jasa yang dialami atau jumlah atribut produk atau jasa yang diterima. Fandy Tjiptono (2005:206) menjelaskan bahwa terdapat hubungan antara ekspektasi dan persepsi yang dapat mempengaruhi kepuasan.
Kepuasan dapat diartikan sebagai respon terhadap evaluasi yang dirasakan antara harapan sebelumnya dengan kenyataan yang diterima. Tentunya apabila harapannya lebih tinggi dari kenyataan yang diterima maka pelanggan merasa tidak puas dan mengeluh. Menurut Kotler dan Ketler (2009:161) mengungkapkan bahwa kepuasan adalah persamaan personal dari kesenangan atau kekecewaan sebagai hasil dari perbandingan antara manfaat produk yang dirasakan (or come) terhadap harapan atau pengalaman mereka. Pelanggan yang puas adalah pelanggan yang merasa mendapatkan nilai dari seorang pemasok, produsen atau penyedia jasa. (Irawan,2006:2)

Berdasarkan uraian kerangka pemikiran diatas, maka dapat digambarkan kerangka pemikiran dan paradigma untuk penelitian ini sebagai berikut:

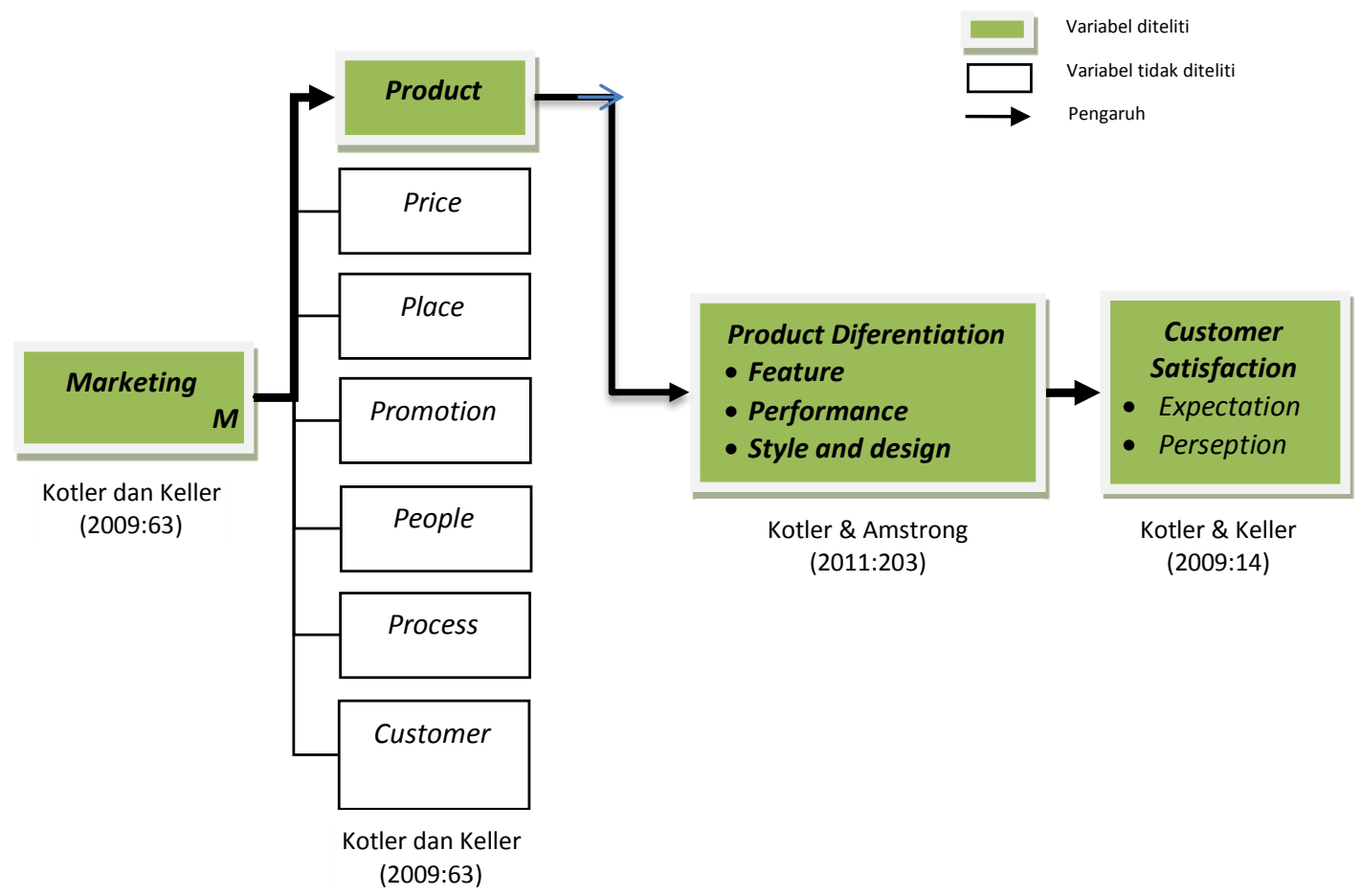

\section{GAMBAR 1 \\ KERANGKA PEMIKIRAN \\ PENGARUH STRATEGI DIFERENSIASI PRODUK MELALUI GREEN TOURISM DESTINATION TERHADAP KEPUASAN BERKUNJUNG}

\subsection{Hipotesis}

Menurut Sugiyono (2010:93), hipotesis adalah jawaban sementara terhadap rumusan masalah penelitian, hal tersebut dikarenakan jawaban tang diberikan baru didasarkan pada teori yang relevan, belum didasarkan pada fakta-fakta empiris yang diperoleh 
melalui pengumpulan data. Untuk itu perlu dilakukan pengujian hipotesis melalui penelitian yang bersangkutan. Berdasarkan teori-teori yang telah dikemukakan maka diajukan hipotesis yang akan dibuktikan melalui penelitian. Penyusunan hipotesis penelitian ini, didukung oleh beberapa premis yang mendukung bahwa strategi diferensiasi produk terhadap kepuasan berkunjung sebagai berikut:

1. Kotler (2009:368), produk mengacu pada dasar kebutuhan dari fakta-fakta sehingga konsumen mendapatkan kepuasan dari sebuah produk.

2. Menurut Kotler dan Ketler (2009:161) mengungkapkan bahwa kepuasan adalah persamaan personal dari kesenangan atau kekecewaan sebagai hasil dari perbandingan antara manfaat produk yang dirasakan (or come) terhadap harapan atau pengalaman mereka.

3. Case dan Fair (2007:357) menjelaskan bahwa agar diferensiasi produk bisa sukses, konsumen harus tahu tentang kualitas dan ketersediaan produk. Diferensiasi produk ini mencakup semua upaya yang dilakukan perusahaan untuk menciptakan perbedaan antara pesaing dengan tujuan memberikan nilai dan kepuasan yang terbaik untuk konsumen.

4. Menurut Mowen dan Miror (2007), diferensiasi adalah proses manipulasi bauran pemasaran sehingga para konsumen dapat merasakan kepuasan dan perbedaan yang berarti antara merek tersebut dengan pesaing.

5. Irawan (2006:2), pelanggan yang puas adalah pelanggan yang merasa mendapatkan nilai dari seorang pemasok, produsen atau penyedia jasa. Nilai bagi pelanggan adalah produk berkualitas, maka kepuasan terjadi saat pelanggan mendapatkan produk yang berkualitas.

Berdasarkan kerangka pemikiran dan premis di atas, maka hipotesis yang diajukan oleh penulis dalam penelitian ini adalah terdapat pengaruh yang signifikan baik secara parsial maupun simultan dalam diferensiasi produk green tourism destination terhadap kepuasan berkunjung di Pulau Sikuai Provinsi Sumatera Barat.

\section{METODE PENELITIAN}

\subsection{Objek Penelitian}

Penelitian ini meneliti tentang pemasaran Pulau Sikuai yang diterapkan terhadap kepuasan berkunjung. Penelitian ini meneliti dua variabel yaitu variabel bebas dan variabel terikat. Adapun variabel bebas (independent) yang digunakan dalam penelitian ini adalah diferensiasi produk dengan $\mathrm{X}$ yang terdiri dari (X1) performance, (X2) features dan (X3) style and design. Kepuasan berkunjung sebagai Y merupakan variabel tidak bebas (dipenden) yang terdiri dari ekspektasi dan persepsi. Variabel yang diteliti yaitu diferensiasi produk terhadap kepuasan berkunjung. Objek penelitian adalah tanggapan responden mengenai diferensiasi produk dan kepuasan berkunjung, sedangkan unit analisis atau responden dalam penelitian ini adalah pengunjung Pulai Sikuai Sumatera Barat.

\subsection{Metode Penelitian}

Metode penelitian yang digunakan oleh peneliti berdasarkan atas tujuan penelitiannya adalah penelitian deskriptif dan verifikatif. Metode penelitian deskriptif adalah penelitian yang berusaha mendeskripsikan atau menggambarkan fenomena atau hubungan antar fenomena yang diteliti sistematis, faktual, dan akurat (Kusmayadi dan Endar Sugiarto, 2000:29). Penelitian deskriptif menurut Sugiama (2008:37) adalah riset yang berupaya mengumpulkan data, menganalisis secara kritis atas data-data tersebut dan menyimpulkan berdasarkan fakta-fakta pada masa penelitian berlangsung atau masa sekarang. Penelitian deskriptif bertujuan mendapatkan gambaran untuk memperoleh gambaran tentang variabel.

Sifat penelitian verifikatif pada dasarnya ingin menguji kebenaran dari suatu hipotesis yang dilaksanakan melalui pengumpulan data dilapangan dimana dalam penelitian ini akan diuji apakah terdapat pengaruh pemasaran dengan menerapkan diferensiasi produk terhadap kepuasan pengunjung yang datang di Pulau Sikuai Sumatera Barat.

Berdasarkan jenis penelitian ini adalah deskriptif dan verifikatif yang dilaksanakan melalui pengumpulan data di lapangan, maka metode penelitian yang digunakan 
adalah metode deskriptif survey dan metode explanatory survey.

Menurut Kerlinger, yang dikutip oleh Sugiyono (2010:7), yang dimaksud metode survei yaitu: Metode penelitian yang dilakukan pada populasi besar maupun kecil tapi data yang dipelajari adalah data dari sampel yang diambil dari populasi tersebut, sehingga ditemukan kejadian-kejadian relatif. Distribusi dan hubungan-hubungan antar variabel sosiologis maupun psikologis.

Pendekatan yang paling cocok untuk mngumpulan informasi deskriptif yaitu dengan menggunakan penelitian survey (Kotler dan Amstrong, 2007:161). Dalam penelitian survey, informasi dikumpulkan dari responden dengan menggunakan kuesioner. Dengan demikian, penelitian survey adalah penelitian yang mengambil sampel dari satu populasi dan menggunakan kuesioner sebagai alat pengumpulan data yang pokok (Singarimbun dan Effendi, 2005:3)

Aaker, Kumar dan Day (2008:226) mengemukakan dua keuntungan dari penelitian survey. Pertama, penelitian survey dapat mengumpulkan data yang banyak mengenai responden individu dalam suatu waktu. Kedua, penelitian survey dapat dilakukan untuk tujuan penelitian deskriptif maupun kausal. Adapun metode survey yang peneliti gunakan adalah langsung membagikannya kepada pengunjung dan mengumpulkannya kembali.

Analisis data dalam penelitian ini dinamakan analisis cross sectional, karena pengumpulan data dilakukan pada satu kurun waktu (at a point of time) yakni kurang dari satu tahun. Metode crosssectional adalah metode penelitian dengan cara mempelajari objek dalam kurun waktu tertentu (tidak kesinambungan dalam jangka waktu panjang).

\subsection{Operasional Variabel}

Penelitian ini terdiri dari dua variabel utama, yaitu diferensiasi produk dan kepuasan berkunjung. Secara lengkap operasionalisasi variable dapat dilihat pada tabel berikut:

OPERASIONALISASI VARIABEL

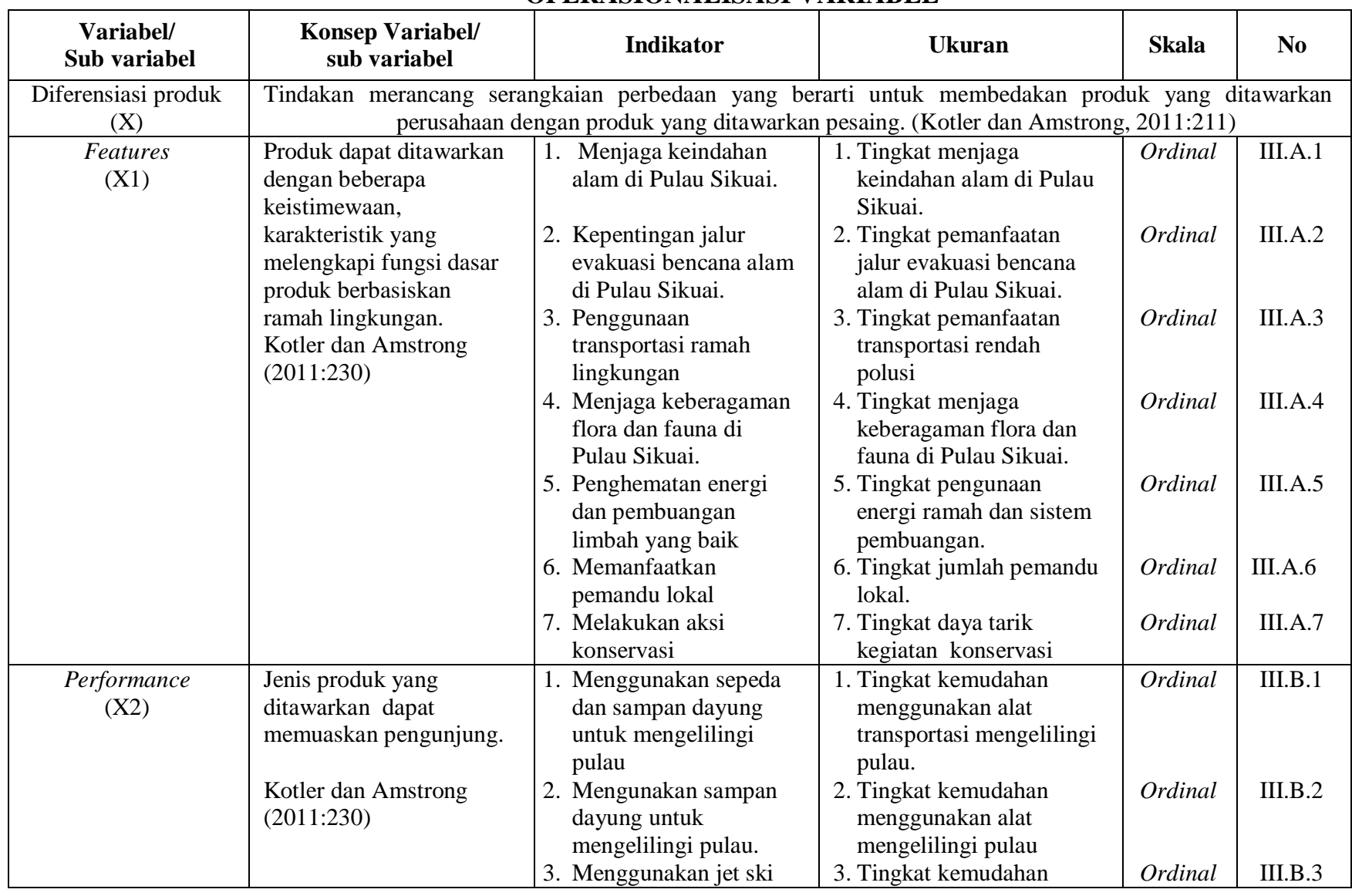




\begin{tabular}{|c|c|c|c|c|c|}
\hline & & $\begin{array}{l}\text { untuk mengelilingi } \\
\text { pulau } \\
\text { 4. Menanam terumbu } \\
\text { karang untuk } \\
\text { konservasi. } \\
\text { 5. Menggunakan bak } \\
\text { penampungan } \\
\text { pembuangan khusus. } \\
\text { 6. Hiking, trekking, } \\
\text { birding atau } \\
\text { birdwatching } \\
\text { (pengamatan burung), } \\
\text { snorkeling, dan diving. }\end{array}$ & $\begin{array}{l}\text { menggunakan alat } \\
\text { mengelilingi pulau } \\
\text { 4. Tingkat intensitas } \\
\text { menanam terumbu } \\
\text { karang } \\
\text { 5. Tingkat kebersihan } \\
\text { pengelolaan limbah } \\
\text { pembuangan. } \\
\text { 6. Tingkat kemudahan } \\
\text { dalam melakukan } \\
\text { Hiking, trekking, birding } \\
\text { atau birdwatching } \\
\text { (pengamatan burung), } \\
\text { snorkeling, dan diving. }\end{array}$ & $\begin{array}{l}\text { Ordinal } \\
\text { Ordinal } \\
\text { Ordinal }\end{array}$ & $\begin{array}{l}\text { III.B.4 } \\
\text { III.B.5 } \\
\text { III.B.6 }\end{array}$ \\
\hline $\begin{array}{l}\text { Style \& Design } \\
\quad \text { (X3) }\end{array}$ & $\begin{array}{l}\text { Menggambarkan } \\
\text { penampilan dan perasaan } \\
\text { produk itu bagi pembeli. } \\
\text { Gaya memiliki } \\
\text { keunggulan kompetitif } \\
\text { yang sukar ditiru. } \\
\text { Kotler dan Amstrong } \\
(2011: 230)\end{array}$ & $\begin{array}{l}\text { 1. Kemenarikan arsitektur } \\
\text { bangunan yang ramah } \\
\text { lingkungan di Pulau } \\
\text { Sikuai. } \\
\text { 2. Kemenarikan tata letak } \\
\text { di Pulau Sikuai. } \\
\text { 3. Keunggulan disain } \\
\text { promosi Pulau Sikuai } \\
\text { dengan pulau lainnya. } \\
\text { 4. Kemenarikan tata } \\
\text { rancangan fasilitas di } \\
\text { Pulau Sikuai. } \\
\text { 5. Penggunaan bahan } \\
\text { promosi yang ramah } \\
\text { lingkungan } \\
\text { 6. Sistem jalan setapak } \\
\text { yang memperhatikan } \\
\text { pola perjalanan dan } \\
\text { pola habitat hidup liar }\end{array}$ & $\begin{array}{l}\text { 1. Tingkat kemenarikan } \\
\text { arsitektur bangunan yang } \\
\text { ramah lingkungan di } \\
\text { Pulau Sikuai. } \\
\text { 2. Tingkat kemenarikan tata } \\
\text { letak di Pulau Sikuai. } \\
\text { 3. Tingkat keunggulan } \\
\text { desain promosi dengan } \\
\text { pulau lain } \\
\text { 4. Tingkat kemenarikan tata } \\
\text { rancangan fasilitas di } \\
\text { Pulau Sikuai. } \\
\text { 5. Tingkat penggunaan } \\
\text { bahan promosi yang } \\
\text { ramah lingkungan } \\
\text { 6. Tingkat keunikan jalan } \\
\text { setapak yang } \\
\text { memperhatikan pola } \\
\text { perjalanan dan pola } \\
\text { habitat hidup liar }\end{array}$ & $\begin{array}{l}\text { Ordinal } \\
\text { Ordinal } \\
\text { Ordinal } \\
\text { Ordinal } \\
\text { Ordinal } \\
\text { Ordinal }\end{array}$ & $\begin{array}{l}\text { III.C.1 } \\
\text { III.C.2 } \\
\text { III.C.3 } \\
\text { III.C.4 } \\
\text { III.C.5 } \\
\text { III.C.6 }\end{array}$ \\
\hline $\begin{array}{l}\text { Kepuasanberkunjung } \\
\text { (Y) }\end{array}$ & \multicolumn{5}{|c|}{$\begin{array}{l}\text { Kepuasan adalah perasaan senang atau kecewa seseorang yang timbul karena membandingkan kinerja } \\
\text { yang dipersepsikan produk (hasil) terhadap ekspektasi mereka. (Koller dan Keller, 2009:161) }\end{array}$} \\
\hline & & $\begin{array}{l}\text { gan antara kenyataan dan } \\
\text { harapan }(\mathrm{P} \& \mathrm{E}) \text { dengan } \\
\text { feature yang dirasakan. }\end{array}$ & $\begin{array}{l}\text { 1. Tingkat perbandingan } \\
\text { antara kenyataan dan } \\
\text { harapan (P\&E) dengan } \\
\text { menjaga keindahan alam } \\
\text { di Pulau Sikuai. } \\
\text { 2. Tingkat perbandingan } \\
\text { antara kenyataan dan } \\
\text { harapan (P\&E) dengan } \\
\text { kepentingan jalur } \\
\text { evakuasi bencana alam di } \\
\text { Pulau Sikuai. } \\
\text { 3. Tingkat perbandingan } \\
\text { antara kenyataan dan } \\
\text { harapan (P\&E) dengan } \\
\text { penggunaan transportasi } \\
\text { ramah lingkungan di } \\
\text { Pulau Sikuai. } \\
\text { 4. Tingkat perbandingan } \\
\text { antara kenyataan dan } \\
\text { harapan (P\&E) dengan } \\
\text { menjaga keberagaman } \\
\text { flora dan fauna Pulau } \\
\text { Sikuai } \\
\text { 5. Tingkat perbandingan } \\
\text { antara kenyataan dan } \\
\text { harapan (P\&E) dengan } \\
\text { penghematan energi dan } \\
\text { pembuangan limbah }\end{array}$ & $\begin{array}{l}\text { Ordinal } \\
\text { Ordinal } \\
\text { Ordinal } \\
\text { Ordinal }\end{array}$ & III.A.3 \\
\hline
\end{tabular}




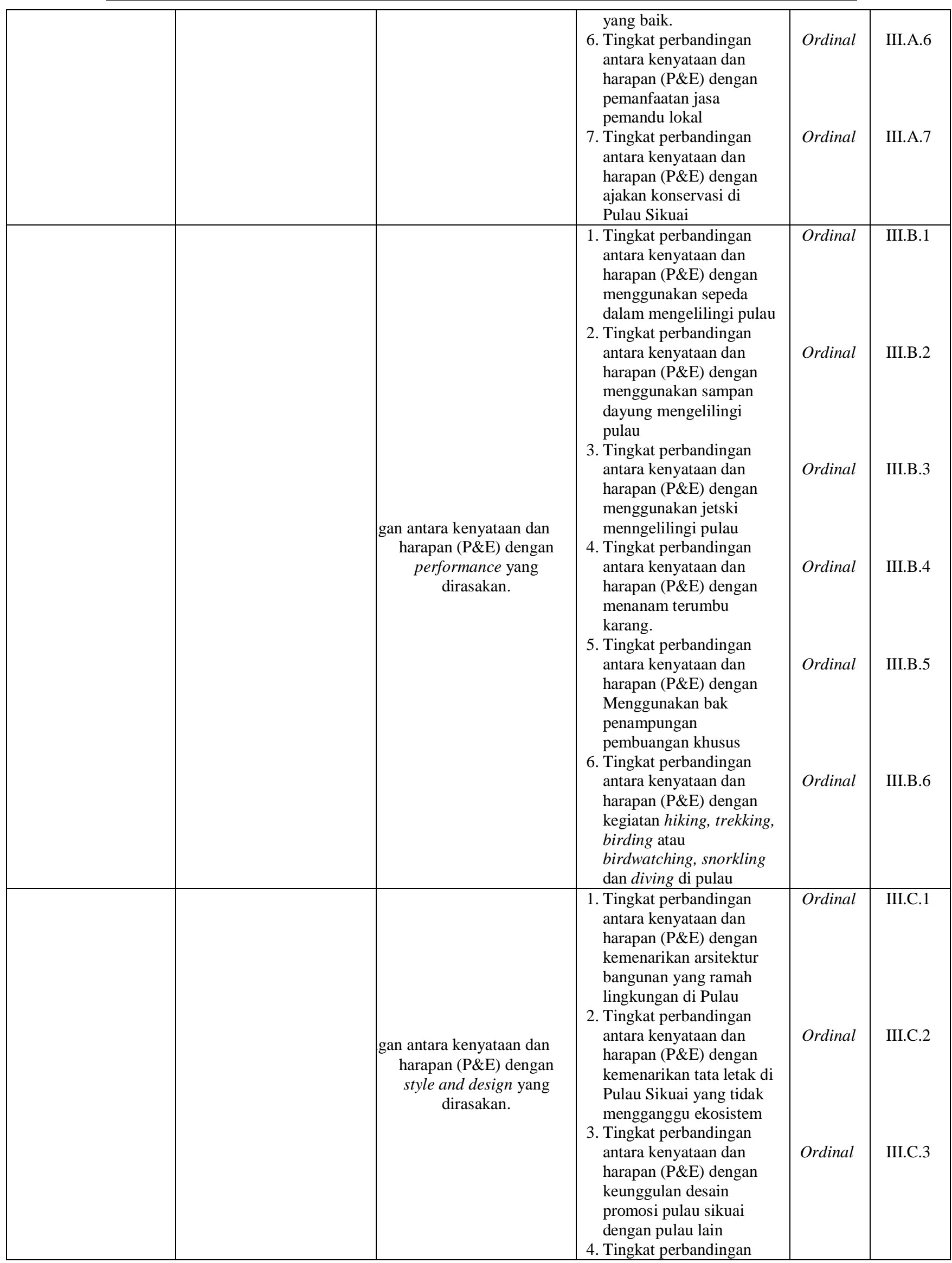




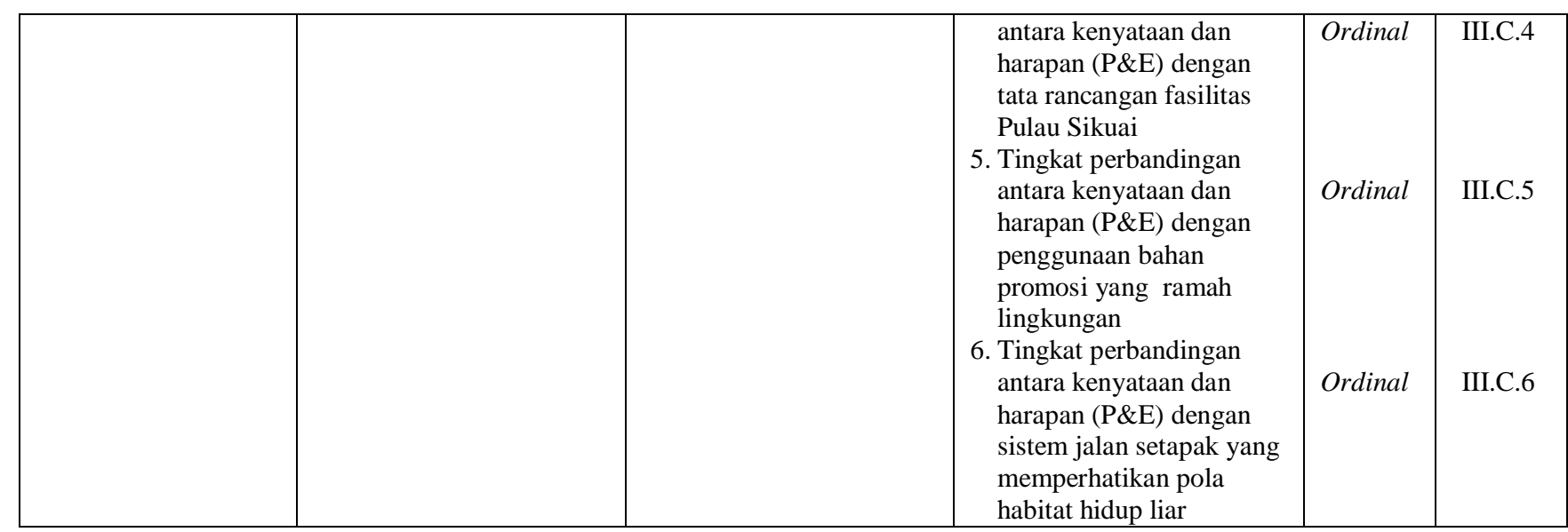

\subsection{Metode Penarikan Sampel}

Menurut Sugiono (2010:116) "Bila populasi besar dan peneliti tidak dapat mempelajari semua yang ada maka peneliti dapat menggunakan sampel yang diambil dari populasi tersebut".

Menurut Husein Umar (2006:59), mengemukakan bahwa untuk menghitung besarnya ukuran sampel dapat dilakukan dengan menggunakan teknik slovin dengan rumus ::

$$
n=\frac{N}{1+N e^{2}}
$$

\section{Dimana}

$N=$ Jumlah Populasi $n=$ jumlah sampel minimum $e=$ persentase kelonggaran ketelitian karena kesalahan pengambilan sampel

Berdasarkan rumus Slovin, maka ukuran sampel pada penelitian ini adalah sebagai berikut:

$$
\begin{aligned}
& \mathrm{n}=\frac{334}{1+\left(334 \times(0.1)^{2}\right)} \\
& \mathrm{n}=76,958 \\
& \mathrm{n}=80
\end{aligned}
$$

Berdasarkan hasil dari perhitungan diatas maka jumlah sampel minimal yang diteliti adalah berjumlah 80 responden.

\subsection{Prosedur Pengumpulan Data}

Teknik pengumpulan data merupakan suatu proses pengadaan data untuk kepentingan penelitian. Data yang telah berkumpul digunakan untuk hipotesis yang telah dirumuskan. Teknik pengumpulan data yang diperoleh penulis adalah:
1. Wawancara
2. Observasi
3. Kuesioner
4. Studi Literatur

\subsection{Pengujian Hipotesis}

Teknik untuk menguji data yang digunakan dalam penelitian ini adalah regresi linier berganda (multiple linier regression). Analisis regresi linier berganda adalah suatu alat analisis peramalan nilai pengaruh dua atau lebih variabel bebas $(\mathrm{X})$ terhadap variabel terikat (Y) untuk membuktikan ada atau tidaknya hubungan kasual antara dua variabel bebas atau lebih.

Persamaan regresi berganda lima variabel bebas dirumuskan sebagai berikut: Keterangan:

$\mathrm{Y}=\mathrm{a}+\mathrm{b}_{1} \mathrm{X}_{1}+\mathrm{b}_{2} \mathrm{X}_{2}+\mathrm{b}_{3} \mathrm{X}_{3}$

$\mathrm{Y}=$ Subyek dalam variabel dependen yang diprediksikan (kepuasan).

$\mathrm{a}=$ Harga $\mathrm{Y}$ bila $\mathrm{X}=0$

$\mathrm{b}=$ Angka arah atau koefisien regresi, yang menunjukan angka peningkatan ataupun penurunan variabel dependen yang didasarkan pada variabel independen. Bila $b$ (+) maka naik, dan bila (-) maka terjadi penurunan.

$\mathrm{X}=$ Subyek pada variabel independen yang mempunyai nilai tertentu. $\mathrm{X} 1$, $\mathrm{X} 2, \mathrm{X} 3$ = variabel penyebab $(\mathrm{X} 1=$ features), (X2 = Performance), dan (X3 = style and design)

Menurut Sugiyono (2010:277) analisis regresi berganda digunakan bila 
penelitian bermaksud meramalkan bagaimana keadaan (naik turnnya) variabel dependen (kriterium), bila dua atau lebih variabel independent sebagai faktor prediktor dimanipulasi (dinaik-turunkan nilainya). Analisis regresi berganda akan dilakukan bila jumlah variabel independen minimal dua atau lebih. Menerjamahkan ke dalam beberapa sub hipotesis yang menyatakan pengaruh sub variabel independen yang paling dominan terhadap variabel dependen, lebih jelasnya dapat dilihat pada Gambar berikut:

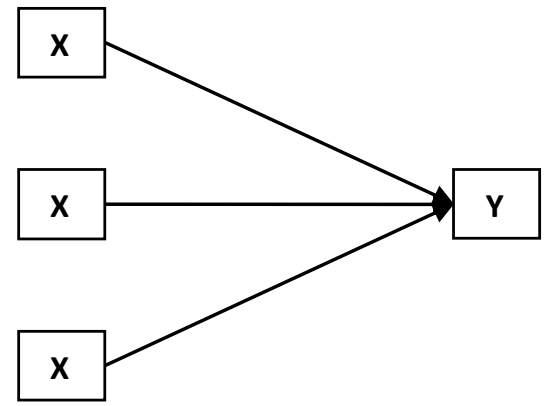

GAMBAR

REGRESI BERGANDA

Keterangan:

$\mathrm{X} 1=$ features

$\mathrm{X} 2=$ Performance

$\mathrm{X} 3$ = Style and design

$\mathrm{Y}=$ Kepuasan berkunjung

$\begin{array}{lllr}\text { IV. HASIL } & \text { PENELITIAN } & \text { DAN } \\ \text { PEMBAHASAN } & & & \\ \text { 4.1 Pengujian } & \text { Hipotesis dan uji }\end{array}$ 4.1 Pengujian Hipotesis dan
Signifikasi Secara Simultan (Uji F)

Untuk mengetahui tingkat signifikasi konstrubusi bebas dalam menjelaskan variabel terikat dapat digunakan uji $\mathrm{F}$, untuk lebih jelasnya mengenai output ANOVA dapat dilihat pada Tabel berikut :

TABEL OUTPUT ANOVA

\begin{tabular}{|l|c|c|c|c|c|}
\hline Model & $\begin{array}{c}\text { Sum } \\
\text { of } \\
\text { Squar } \\
\text { es }\end{array}$ & df & $\begin{array}{c}\text { Mean } \\
\text { Square }\end{array}$ & F & Sig \\
\hline Regressior &, 446 & 3 &, 149 & 31,455 &, $000 \mathrm{a}$ \\
\hline Residua &, 359 & 76 &, 005 & & \\
\hline Total &, 805 & 79 & & & \\
\hline
\end{tabular}

a. Predictors : (constant), $\mathrm{X} 3, \mathrm{X} 2, \mathrm{X} 1$

b. Dependent Variable : Y
Berdasarkan Tabel, diketahui nilai $F_{\text {hitung }}$ sebesar 31,455 dengan p-value (sig) 0,000 . Dengan $\alpha=0,05$ serta derajat kebebasan $\mathrm{v}_{1}=76(\mathrm{n}-(\mathrm{k}+1))$ dan $\mathrm{v}_{2}=3$, maka diperoleh nilai $F_{\text {tabel }}$ 2,725. Dikarenakan nilai $F_{\text {hitung }}>F_{\text {tabel }}(31,455>$ 2,725) maka $\mathrm{H}_{0}$ ditolak, artinya variabel bebas (X) secara simultan berpengaruh signifikan terhadap kepuasan berkunjung (Y).

$\mathrm{H}_{\mathrm{a}} \neq 0$, Terdapat pengaruh yang signifikan antara diferensiasi produk green tourism destination di Pulau Sikuai terhadap kepuasan berkunjung.

\subsection{Pengujian Hipotesis dan Uji \\ Signifikansi Secara Parsial (Uji-t)}

Pengujian ini bertujuan untuk melihat pengaruh antara masing-masing variabel independen mempengaruhi variabel dependen signifikan atau tidak dan untuk mencari informasi dari keseluruhan variabel bebas yaitu diferensiasi produk green tourism destination di Pulau Sikuai Padang, variabel mana yang pengaruhnya paling dominan atau paling besar. untuk tujuan itu dapat dilihat melalui tabel koefisien regresi berikut ini

TABEL

OUTPUT KOEFISIEN REGRESI

\begin{tabular}{|l|c|c|c|c|c|}
\hline \multirow{2}{*}{ Model } & \multicolumn{2}{|c|}{$\begin{array}{c}\text { Unstandardized } \\
\text { Coefficients }\end{array}$} & $\begin{array}{c}\text { Standardized } \\
\text { coefficients }\end{array}$ & \multirow{2}{*}{ t } & \multirow{2}{*}{ Sig. } \\
\cline { 2 - 5 } & $\mathbf{B}$ & Std & Beta & & \\
\hline Constant & 0,545 & 0,053 & & 102 & 0,00 \\
\hline Features & 0,015 & 0,03 & 0,510 & 5,3 & 0,00 \\
\hline Perform & 0,011 & 0,003 & 0,299 & 3,27 & 0,00 \\
\hline $\begin{array}{l}\text { Style and } \\
\text { design }\end{array}$ & 0,003 & 0,003 & 0,095 & 1,16 & 0,24 \\
\hline
\end{tabular}

Berdasarkan Tabel, secara persial menunjukan bahwa variabel bebas diferensiasi produk yang terdiri dari, features $\left(\mathrm{X}_{1}\right)$, performance $\left(\mathrm{X}_{2}\right)$, style and design $\left(\mathrm{X}_{3}\right)$ memiliki pengaruh terhadap kepuasan berkunjung $(\mathrm{Y})$. Hal ini berarti hipotesis yang diajukan di terima semua. Hal ini bisa yang dapat dijelaskan rinci sebagai berikut:

1. Terdapat pengaruh yang signifikana antara sub variabel features $\left(\mathrm{X}_{1}\right)$ 
terhadap kepuasan berkunjung $\left(\mathrm{t}_{\text {hitung }}=1,991>5.733=\mathrm{t}_{\text {hitung }}\right)$, demikian juga nilai sig $=0,000<0,05$ dengan nilai koefisien regresi 0,015. Sehingga dapat dikatakan bahwa nilai $\mathrm{t}_{\text {hitung }}>\mathrm{t}_{\text {tabel}}$, maka $\mathrm{H}_{0}$ ditolak, artinya features berpengaruh signifikan terhadap kepuasan berkunjung.

2. Terdapat pengaruh yang signifikan antara sub variabel performance $\left(\mathrm{X}_{2}\right)$ terhadap kepuasan berkunjung $\left(\mathrm{t}_{\text {hitung }}=1,991>3.271=\mathrm{t}_{\text {hitung }}\right)$,

demikian juga nilai sig $=0,000<0,05$ dengan nilai koefisien regresi 0,011. Sehingga nilai $t_{\text {hitung }}>t_{\text {tabel }}$, maka $\mathrm{H}_{0}$ ditolak, artinya performance berpengaruh signifikan terhadap kepuasan berkunjung.

3. Sub variabel style and design $\left(\mathrm{X}_{3}\right)$ terhadap kepuasan berkunjung ( $\mathrm{t}_{\text {hitung }}=1,991>1.162=\mathrm{t}_{\text {hitung }}$ ),

demikian juga nilai sig $=0,249<0,05$ dengan nilai koefisien regresi 0,03 . Oleh karena diperoleh nilai $t_{\text {hitung }}$ untuk $\mathrm{X}_{3}$ sebesar 1,162 dan $t_{\text {tabel }}$ 1,991 maka nilai $\mathrm{t}_{\text {hitung }}<\mathrm{t}_{\text {tabel }}$, maka $\mathrm{H}_{0}$ diterima, artinya style and design berpengaruh terhadap kepuasan berkunjung, namun tidak signifikan.

Dapat dilihat bahwa sub variabel features mempunyai pengaruh yang besar. Karena tingkat signifikasinya yaitu 0,000 dan nilai $t_{\text {hitung }}$ lebih besar dari sub variable yang lain.

\subsection{Persamaan Regresi Linier Berganda}

Hasil Analisis data dengan bantuan program. SPSS 18 for windows diperoleh persamaaan regresi sebagai berikut:

$$
\mathrm{Y}=\mathrm{b}_{0}+\mathrm{b}_{1} \mathrm{X}_{1}+\mathrm{b}_{2} \mathrm{X}_{2}+\mathrm{b}_{3} \mathrm{X}_{3}
$$

Dimana:

$\begin{array}{lll}\text { X1 } & : & \text { Features } \\ \text { X2 } & : & \text { Performance } \\ \text { X3 } & : & \text { Style and design } \\ \text { Y } & : & \text { Kepuasan Berkunjung } \\ \text { b0 } & : & \text { Intersep } \\ \text { b1,..,b2 } & : & \text { Koefisien regresi }\end{array}$

Berdasarkan output Tabel 4.69 diketahui nilai kontstanta dan koefisien regresi sehingga dapat dibentuk persamaan regresi linier berganda sebagai berikut:

$$
\begin{gathered}
\mathrm{Y}=0,545+0,015 \mathrm{X}_{1}+0,011 \\
\mathrm{X}_{2}
\end{gathered}
$$

Persamaan di atas dapat diartikan sebagai berikut:

$\mathrm{b}_{0}=0,545$ artinya jika variabel $\mathrm{X}_{1}, \mathrm{X}_{2}$, dan $\mathrm{X}_{3}$ bernilai nol, maka variabel $\mathrm{Y}$ akan bernilai 0,545 satuan.

$\mathrm{b}_{1}=0,015$ artinya jika features $\left(\mathrm{X}_{1}\right)$ meningkat sebesar satu satuan dan variabel lainnya konstan, maka variabel Y akan meningkat sebesar 0,015 satuan.

$\mathrm{b}_{2}=0,011$ artinya jika performance $\left(\mathrm{X}_{2}\right)$ meningkat sebesar satu satuan dan variabel lainnya konstan, maka variabel $\mathrm{Y}$ akan meningkat sebesar 0,011 satuan.

Untuk mengetahui seberapa besar pengaruh secara parsial atau per individu variabel independen terhadap variabel dependen $\left(\mathrm{X}_{1}\right.$ $\mathrm{Y}, \mathrm{X}_{2}-\mathrm{Y}$, dan $\mathrm{X}_{3}-\mathrm{Y}$ ) maka metode yang digunakan adalah Koefisien Beta $\mathrm{X}$ Zeroorder:

$$
\begin{aligned}
1 \mathrm{X} 1 & =0,510 \times 0,683=0,3482=34,82 \% \\
2 \mathrm{X} 2 & =0,2990 \times 0,586=0,1752=17,52 \%
\end{aligned}
$$

Berdasarkan hasil uji individu diatas diketahui bahwa variabel $\mathrm{X}_{1}$ (Features) terhadap variabel $\mathrm{Y}$ (kepuasan berkunjung) memiliki pengaruh sebesar 0,3482 atau $34,82 \%, \mathrm{X}_{2}$ (performance) terhadap variabel $\mathrm{Y}$ (Kepuasan Berkunjung) memiliki pengaruh sebesar 0,1752 atau $17,52 \%, \mathrm{X}_{3}$ (style and design) terhadap variabel $\mathrm{Y}$ (kepuasan berkunjung) memiliki pengaruh sebesar 0,0306 atau 3,06\%.

\section{KESIMPULAN}

\subsection{Kesimpulan}

Berdasarkan hasil penelitian yang telah dilakukan dengan menggunakan analisa deskriptif dan verifikatif antara pengaruh diferensiasi produk green tourism destination terhadap kepuasan berkunjung di Pualau Sikuai Padang Sumatera, dapat diambil kesimpulan sebagai berikut.

1. Diferensiasi produk green tourism destination yang diterapkan oleh Pulau Sikuai yang terdiri oleh features, performance, style and design. Secara keseluruhan pengunjung Pulau Sikuai memiliki penilaian yang berbeda-beda. Penilaian terhadap features memiliki 
penilian yang paling tinggi karena merupakan letak keistimewaan yang green tourism destination merupakan diferensiasi produk dari Pulau Sikuai, dimana diantaranya para pengunjung diajak untuk melakukan konservasi dan memanfaatkan pemandu jasa lokal yang tersedia di Pulau Sikuai. Penilaian terhadap performance lebih sedikit dikarenakan para pengunjung sedikit terbebankan oleh biaya tambahan yang diberlakukan pihak Pulau Sikuai.

2. Penilaian terhadap kepuasan berkunjung di Pulau Sikuai yang berdasarkan oleh features, performance, style and design memiliki penilaian tertinggi adalah kepuasan atas features, karena pengunjung diajak untuk benar-benar memanfaatkan alam dengan cara yang mudah. Hal ini menunjukan bahwa tingkat kepentingan yang diharapkan pengunjung dengan tingkat kinerja terhadap features yang diberikan kepada pengunjung memiliki tingkat kesesuian yang tinggi, dalam arti kinerja features hampir bisa memenuhi tingkat kepentingan wisatawan jika dibandingkan dengan performance

3. Berdasarkan pengujian hipotesis menunjukan diferensiasi produk green tourism destination yang terdiri dari features dan performance memiliki pengaruh yang signifikan terhadap kepuasan berkunjung di Pulau Sikuai, baik itu secara simultan maupun parsial. Secara parsial maupun simultan, features memiliki pengaruh yang cukup tinggi terhadap kepuasan berkunjung di Pulau Sikuai dibandingkan dengan performance.

\section{DAFTAR PUSTAKA}

Amir, M. Taufiq.(2005). Dinamika Pemasaran. Jakarta : PT. Rajagrafindo Persada.

Assauri, Sofyan. (2006). Manajemen Pemasaran. Jakarta : PT. Rajagrafindo Persada.

Buchari Alma., (2007). Manajemen Pemasaran dan Pemasaran Jasa. Bandung : Alfabeta.

Case , E Karl dan Fair, C ray.(2007).Prinsip-prinsip Ekonomi.Jakarta:erlangga.

Chafid Fandeli., Mukhlison., (2000), Pengusahaan Ekowisata
Fakultas,Kehutanan Univ. Gadjah Mada Yogyakarta

Fandy Tjiptono, Gregorius Chandra dan Dedi Adriana (2008). Pemasaran Stratrgik Yogyakarata.Andi

Ginting (2005) Pengantar Pariwisata. Jakarta. PT Gramedia

Husein Umar., (2002). Metode Riset Bisnis, Jakarta : Gramedia Pustaka Utama.

Harun Al Rasyid (1994). Teknik Penarikan Sampel dan penyusunan Skala.Universitas Padjadjaran, Bandung

Hermawan Kartajaya, (2005), Marketing In Venus, Jakarta: PT.Gramedia Pustaka Utama.

Kotler, Philip dan Amstrong, Garry., 2011. Principle of Marketing Edition. New Jersey : Prentice Hall Inc.

Kotler, Philip \& Amstrong, Gary. 2009. Principles Of Management. 13nd Edition. Penerbit Pearson Prentice Hall. New Jersey.

Kotler, Philip dan Amstrong, Garry., 2008. Principle of Marketing, $11^{\text {th }}$ Edition. New Jersey : Prentice Hall Inc.

Kotler, Philip \& Keller, Kevin. 2011. Marketing Management. 14th Edition. Penerbit Pearson Prentice Hall. New Jersey.

Kotler, Philip \& Keller, Kevin. 2009. Marketing Management. 13rd Edition. Penerbit Pearson Prentice Hall. New Jersey.

Kotler, Philip. (2008). Marketing Management. New Jersey: Prentice Hall.

Mason, Robert, D, (2000), Teknik Statistika Untuk Bisnis dan Ekonomi, Edisi Kesembilan, Erlangga, Jakarta

Mohammad Nazir. 2006. Metodologi Penelitian. Jakarta: Ghalia Indonesia

Mowen, Jhon C. dan Michael Miror. 2005. Perilaku Konsumen. Jakarta : Erlangga.

Oka A. Yoeti.2005.Ekonomi Pariwisata. Penerbit Kompas. Jakarta

Pendit, Nyoman S. 2006. Ilmu Pariwisata Sebuah Pengantar Perdana. Jakarta: PT Pradnya Paramita.

Sugiyono., (2010), Metode Penelitian Bisnis, Bandung : Alfabeta.

Suswantoro (2007) Dasar-dasar pariwisata, Yogyakarta :Andi

Special Report (2002)The U.S. Ecotourism Market, WTO. 
Tourism and Hospitality Management, Vol. 13, No. 3, pp. 547-556, 2007

P. Curtis, J. Mylonakis, T. Ktenidis: Tourism Product Differentiation Strategy The Turkish Tourism Product: Differentiation and Competitivenes. Anatolia: An International Journal of Tourism and Hospitality Research Volume 21, Number 1, pp. 89-106, 2010

Tjiptono, Fandy, Chandra, Gregorius. 2005. Service, Quality, and Satisfaction. Yogyakarta : Andi.

The SafeinHerit Network workshop report: Green Tourism,Norway.2001

Uma Sekaran, 2006, Research Methods For Business. Edisi 4. Jakarta : Salemba Empat.

Umar, Husein 2009. Metode Penelitian untuk Skripsi dan Tesis Edisi Kedua.Jakarta:Rajawali Pers

Umar, Husein. 2006. Metode Penelitian dan Aplikasi Dalam Pemasaran. Jakarta: PT.Gramedia Pustaka

Victor T.C. Middleton, Alan Fyall and Michel Morgan (2008) Tourism Product development

Weaver, David \& Laura Lawton. 2006 Tourism Management: Third Edition. Australia: John Wiley \& Sons Australia,Ltd

Wiwik D Pratiwi, 2006. Seminar Pelatihan Perencanaan Kelautan \& Pesisir ITB.

UU Pariwisata No.10/2009 tentang Pariwisata dan Prinsip Penyelenggaraan Kepariwisataan www.gahawisri.com diakses oleh Dian Permana pada tanggal 12 Februari 2012 pada pukul 15.15 WIB

www.kompasiana.com diakses oleh Dian Permana pada tanggal 02 September 2011 pada pukul 15.00 WIB

www.travelwan.com diakses oleh Dian Permana pada tanggal 02 September 2011 pada pukul 15.16 WIB

www.flasmana.tumblr.com diakses oleh Dian Permana pada tanggal 02 September 2011 pada pukul 15.23 WIB

www.newsikuairesortisland.com diakses oleh Dian Permana pada tanggal 4 Februari 2012 pada pukul 11.00 WIB

www.Sales-And-Marketing-For-You.com diakses oleh Dian Permana pada tanggal 17 Februari 2012 pada pukul 20.50 WIB

www.kompas.com diakses oleh Dian Permana pada tanggal 3 tanggal Mei 2012 pada pukul 13:02 WIB 